\title{
International Journal of Microbiology Research
}

ISSN: 0975-5276 \& E-ISSN: 0975-9174, Volume 5, Issue 4, 2013, pp.-435-438.

Available online at http://www.bioinfopublication.org/jouarchive.php?opt=\&jouid=BPJ0000234

\section{HIGH RISK HPV GENOTYPING AMONG PRIMARY INFERTILE WOMEN}

\section{SHANWARE A.S. ${ }^{*}$, PATIL P. ${ }^{1}$ AND SHEGOKAR V. ${ }^{2}$}

${ }^{1}$ Rajiv Gandhi Biotechnology Centre, L.I.T. Campus, Rashtrasant Tukadoji Maharaj Nagpur University, Nagpur- 440001, MS, India. 2Department of Microbiology, Government Medical College and Hospital, Nagpur- 440003, MS, India.

*Corresponding Author: Email- artishanware@gmail.com

Received: May 21, 2013; Accepted: May 30, 2013

\begin{abstract}
-
Objective- High risk Human Papilloma virus (HPV) infection is often related to cervical cancer. This study investigated the infection of High risk Human Papilloma virus in cervical epithelia among infertile patients.

Materials and Methods- In a prospective study 315 infertile women between the age of 32-50 year were screened for genital infections (Human Papilloma virus in cervical smear) during their first visit to infertility center. Pap smears and swabs specimens were taken from 315 women. Papanicolaou staining method \& cytology were used. Polymerase chain reaction (PCR) was then performed for Papilloma viruses on all patients.
\end{abstract}

Results- Three hundred and fifteen women were recruited. Out of which total no of primary infertile cases were 98 while total no of positive cases were 77 .

Conclusion- Because the study shows the prevalence of High risk HPV infection among infertile patients more careful screening of women by Papsmear in combination with HPV DNA test is recommended.

Keywords- Papanicolaou smear, High risk Human Papilloma virus, primary infertility.

Citation: Shanware A.S., Patil P. and Shegokar V. (2013) High Risk HPV Genotyping Among Primary Infertile Women. International Journal of Microbiology Research, ISSN: 0975-5276 \& E-ISSN: 0975-9174, Volume 5, Issue 4, pp.-435-438.

Copyright: Copyright@2013 Shanware A.S., et al. This is an open-access article distributed under the terms of the Creative Commons Attribution License, which permits unrestricted use, distribution and reproduction in any medium, provided the original author and source are credited.

\section{Introduction}

Human Papilloma virus (HPV) infection is common among young, sexually active women. Human Papilloma viruses are non enveloped, double stranded DNA virus of approximately 8000 base pairs. The viral genome consists of early \& late regions containing open reading frames (ORFs), resulting in translation of functional proteins. The two late region open reading frames (ORFs), $L_{1} \& L_{2}$ encode two structural proteins composing the major and minor capsid proteins, respectively about $15 \%$ of the viral genome, non encoding for proteins, plays a role in regulation of transcription \&viral DNA replication. The early regions ORFs $\left(E_{1}, E_{2}, E_{4}, E_{7}\right)$ are expressed early in the viral life cycle. Three of the early ORFs are the oncogenes $E_{5}, E_{6} \& E_{7}$. Modulating the transformation process. two regulatory proteins $E_{1} \& E-$, modulate replication of transcription [1].

The HPV family consists of 120 types, of which 40 different types can infect the anogenital mucosa [2,3]. Several HPV high risk types such as $16,18,31,33,35 \& 45$ have been implicated with an etiological role in cervical carcinogenesis [4].

Generally it is assumed that integration into the host chromosome leads to distribution of the $E_{1}$ and $E_{2}$ Open reading frames (ORFs) of the virus. the deletion of the $E_{2}$ ORF result in over expression of the oncogenic $E_{6}$ and $E_{7}$ proteins. Overexpression of the $E_{6}$ and $E_{7}$ gene products results in a constant suppression of key cell-cycle control proteins $P_{53} P_{r b}$, respectively, leading to genetic instability and subsequent neoplastic transformation $[5,6]$.

Cervical cancer is one of the most prevalent and important cancers amongst women. In some studies, it is reported as the second most common cancer after breast cancer while others consider it is as the third most common, after breast and lung cancer $[7,8]$. Human Papilloma virus \& its role in Cervical cancer and high frequency of HPV genital infection, detecting high risk genotype of HPV infection is the best approach to prevent malignancy. Unlike other sexually transmitted diseases (std) HPV infection can be asymptomatic without causing specific genital lesions (condyloma acuminate). Due to this features, the patient not be referred for treatment, giving the virus enough time to replicate in cells and to proceed to malignant stages in epithelial cells. On the other hand, transformation of dysplastic lesions into invasive cervical cancer is gradual and without any alarming symptoms in most cases [9].

The role of the cervix in a healthy women is principally concerned with reproduction, it helps to keep the developing fetus in the uterus and has apart to play in the initiation and progression of labor. The mucus produced by the cervix is considered important in female fertility [10]. The cervix is also thought to have a function in the fe- 
male sexual response [11].

Infertility is defined as one year of unprotected coitus without conception. Some fifteen percent of couples in India, as elsewhere are infertile with the population of India at one billion, the number of infertile couples would be well over 20 million much more than the entire population of Australia and New Zealand. Primary infertility is infertility in a couple who have never had a child. Secondary infertility is defined as the inability to conceive after at least one pregnancy. Infertility is highly prevalent in central India, Despite this large burden, very few infertility management programs exist. Consequences of infertility are often severe \& include marital problems, divorce, stigmatization \& depression.

Treatment of CIN can cause scarring of the cervix and removal of cervical mucus-secreting cells [12]. The scarring may result in cervical stenosis [13] and prevent sperm from entering the uterus or cause alterations in the cervical mucus and therefore infertility. The loss of cervical mucus-secreting glands may compromise the cervical immune defense and thus predispose to ascending infection and to premature prelabour rupture of the fetal membrane and even to tubal infertility [14].

The direct risk of HPV infertility can be associated to Cervical cancer and venereal condyloma studies have shown that the Human Papilloma virus in men can decrease the sperm counts and sperm motility. In woman this high risk strains causes precancerous or cancerous condition of the cervix can develop. As abnormal development of cells takes place in the cervix, condition called dysplasia [15].

Dysplasia is the pre malignant squamous cell abnormalities that range from mild, moderate and severe dysplasia and eventually carcinoma insitu, but this classification has been replaced by cervical intraepithelial neoplasia (CIN).

All methods of treatment of cervical intraepithelial neoplasia are surgical, and might differ with histological findings, extension of lesions, adverse reactions and cost effectiveness the age of patient, the possibility of pregnancy, as extensive treatment methods can decrease fertility and pregnancy outcome. Treatment methods are ablative or excisions [16].

Several methods have been employed to detect HPV infection amongst which PCR is considered the most accurate with the very high specificity and sensitivity this study was designed for molecular detection of HPV and its high risk genotypes in the central Indian population.

\section{Result}

In this study 315 woman between the age of 32-50 yrs. were recruited with total no of primary infertile cases were 98 while the total number of positive cases were 77. Percentage distribution of patient with HPV genotype in primary infertile patients with HPV positive PCR were detected in [Fig-1] and the prevalence of high risk HPV $16,18,31,33,35$ are shown the relationship between HPV infection and the age of primary infertile woman screened in this study was shown in [Table-1] and the relation between HPV infection and white discharge complaint of patient was shown in [Table-2] the relation between menstrual history and HPV infection among patient was shown in [Table-3] our findings have shown a rate of pap smear negative in $80 \%$ of infertile cases while $20 \%$ cases are positive for Pap smear. In [Table-4] It is shown that among 77 positive patients for HPV DNA, according to conventional Pap staining method 12 patients was reported positive \& remaining 65 patients was reported negative for HPV. Hence it is concluded from the study that PCR for HPV DNA is more confirmatory \& sensitivity than conventional Pap staining method. According to percentage distribution of patients with high risk HPV genotypes, it is mentioned in the [Table-5] that HPV 16 \& 18 is highly prevalent in primary infertile patients followed by HPV $31,33,35$.

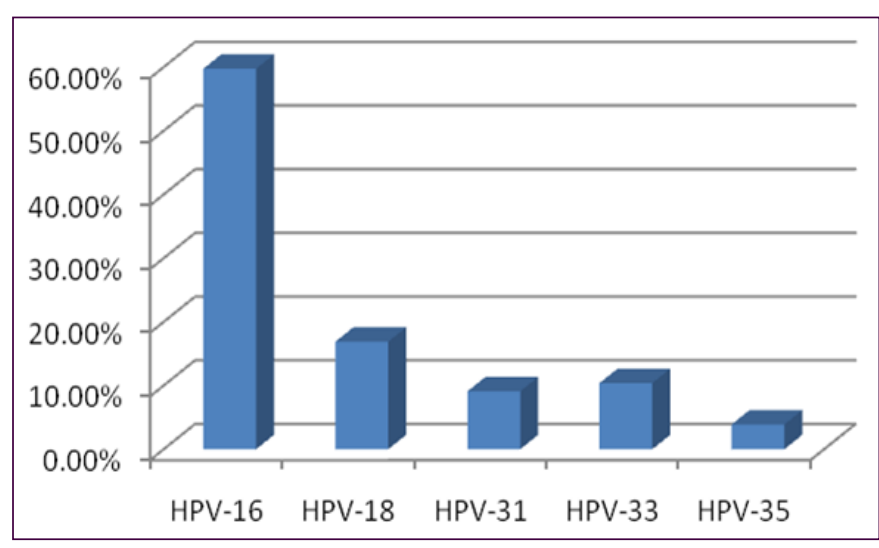

Fig. 1- Percentage distribution of patient with HPV genotypes in primary infertile patents with HPV positive PCR $(n=77)$

Table 1-Correlation between age wise distribution of patients and HPV infection

\begin{tabular}{|c|c|c|c|c|c|c|c|c|}
\hline \multirow{2}{*}{ Age } & \multirow{2}{*}{$\begin{array}{c}\text { Mean } \\
\text { Age }\end{array}$} & \multicolumn{2}{|c|}{$\begin{array}{l}\text { HPV PCR Negative } \\
\quad(n=21)\end{array}$} & \multicolumn{2}{|c|}{$\begin{array}{l}\text { HPV PCR Positive } \\
\quad(n=77)\end{array}$} & \multicolumn{2}{|c|}{ Total $(n=98)$} & \multirow{2}{*}{$\mathrm{p}$-value } \\
\hline & & $n$ & $\%$ & $n$ & $\%$ & n & $\%$ & \\
\hline <38 & $37 \pm 4$ & 3 & 14.3 & 18 & 23.4 & 21 & 21.4 & 0.036 \\
\hline $38-42$ & $39 \pm 2$ & 11 & 52.4 & 37 & 48.1 & 48 & 49 & 0.005 \\
\hline$>42$ & $47 \pm 5$ & 7 & 33.3 & 22 & 28.6 & 29 & 29.6 & 0.022 \\
\hline Total & $42 \pm 8$ & 21 & 100 & 77 & 100 & 98 & 100 & \\
\hline
\end{tabular}

Table 2- Correlation between white discharge and HPV infection

\begin{tabular}{lccccccc} 
White & $\begin{array}{c}\text { HPV PCR Negative } \\
(\mathbf{n}=\mathbf{2 1})\end{array}$ & \multicolumn{2}{c}{$\begin{array}{c}\text { HPV PCR Positive } \\
(\mathbf{n}=\mathbf{7 7})\end{array}$} & \multicolumn{2}{c}{ Total $(\mathbf{n}=\mathbf{9 8})$} & -value \\
Discharge & $\mathbf{n}$ & $\%$ & $\mathbf{n}$ & $\%$ & $\mathbf{n}$ & $\%$ & \\
& 7 & 33.33 & 39 & 50.7 & 46 & 46.94 & 0.022 \\
No & 74 & 66.66 & 38 & 49.3 & 52 & 53.03 & 0.012 \\
Yes & 14 & 100 & 77 & 100 & 98 & 100 & \\
Total & 21 & 100 & & & & &
\end{tabular}

Table 3- Correlation between menstrual history in patient and HPV infection

\begin{tabular}{lccccccc} 
Menstrual & $\begin{array}{c}\text { HPV PCR Negative } \\
(\mathbf{n}=\mathbf{2 1})\end{array}$ & \multicolumn{2}{c}{$\begin{array}{c}\text { HPV PCR Positive } \\
(\mathbf{n}=\mathbf{7 7})\end{array}$} & \multicolumn{2}{c}{ Total $(\mathbf{n}=\mathbf{9 8})$} & p-value \\
History & $\mathbf{n}$ & $\%$ & $\mathbf{n}$ & $\%$ & $\mathbf{n}$ & $\%$ & \\
\hline Irregular & 19 & 90.5 & 69 & 89.6 & 88 & 89.8 & 0.021 \\
Regular & 2 & 9.5 & 8 & 10.4 & 10 & 10.2 & 0.033 \\
Total & 21 & 100 & 77 & 100 & 98 & 100 & \\
\hline
\end{tabular}

Table 4- Correlation between Pap smear result in patient and HPV infection

\begin{tabular}{lccccccc} 
Pap smear & \multicolumn{2}{c}{$\begin{array}{c}\text { HPV PCR Negative } \\
\text { (n=21) }\end{array}$} & \multicolumn{2}{c}{ HPV PCR Positive } & \multicolumn{2}{c}{ Total (n=98) } & p-value \\
& $\mathbf{n}$ & $\%$ & $\mathbf{n}$ & $\%$ & $\mathbf{n}$ & $\%$ & \\
\hline Negative & 13 & 61.9 & 65 & 84.4 & 78 & 79.6 & 0.011 \\
Positive & 8 & 38.1 & 12 & 15.6 & 20 & 20.4 & 0.023 \\
Total & 21 & 100 & 77 & 100 & 98 & 100 & \\
\hline
\end{tabular}

Table 5- Percentage distribution of patient with High risk HPV genotypes 16,18,31,33,35 among primary infertile patents with HPV positive PCR $(n=77)$.

\begin{tabular}{|ccccc|}
\hline HPV-16 & HPV-18 & HPV-31 & HPV-33 & HPV-35 \\
$59.74 \%$ & $16.88 \%$ & $9.09 \%$ & $10.38 \%$ & $3.89 \%$ \\
46 & 13 & 7 & 8 & 3 \\
\hline
\end{tabular}




\section{Methodology}

In the present study 315 women between age group of 35 to 50 years were studied. Out of which total no. of primary infertile cases were 98 . Total no. of positive cases was 77 .

\section{Pap Smearing Method}

A Papanicolaou stain smear test is a screening test to detect an infection, abnormal cellular changes of the female reproductive system. The test was invented by and named after Greek doctor Georgios Papanikolaou.

\section{Sample Collection}

Two Arye spatulas were used for sample collection. A sample of cervical cell is collected by scraping from the outer opening of the cervix by the Arye spatula. One Arye spatula was used to prepare cervical pap smear and another for cervical sample, which was placed in a tube with a phosphate buffered saline (PBS). Smear were fixed in alcohol, stained by Papinicolaou stains (Orange, $G$ Hematoxylin, and EA Polychrome solution consisting of light green solfonated acryl-methane dye, eosin, and Bismark brown). They were covered by glass slips and finally evaluated under microscope.

\section{DNA Extraction}

The set of samples containing exfoliated cervical cells were centrifuged at $3000 \times \mathrm{g}$ for $10 \mathrm{~min}$. The resulting pellet was transferred into a $1.5 \mathrm{ml}$ Eppendorf microtube containing $200 \mathrm{ml}$ digestion buffer (0.2 mol Tris-HCL [pH 7.5], $25 \mathrm{mmol}$ EDTA, $0.3 \mathrm{~mol} \mathrm{Nacl,} 2 \%$ SDS). Subsequently, $20 \mathrm{mg}$ of proteinase $\mathrm{K}$ was added, and the cells were digested at $60^{\circ} \mathrm{C}$ for $2 \mathrm{hrs}$. The digested samples were extracted twice with phenol-chloroform and once with chloroform.

The DNA was precipated by adding $50 \mathrm{ul}, 3 \mathrm{~mol}$ sodium acetate and $1 \mathrm{ml}$ ethanol. After $1 \mathrm{hr}$. at $-70^{\circ} \mathrm{C}$, sample were centrifuged for $10 \mathrm{~min}$ at $14000 \mathrm{rpm}$. The DNA pellet were dried and dissolved in 100 ul TE (10 mmol Tris-HCL [PH 7.5], $0.1 \mathrm{mmol}$ EDTA). The DNA samples were then tested by agarose gel electrophoresis. To ensure that no degradation was occurred during the extraction.

In addition, in order to analyze the quality of the target DNA, betaglobin (positive sample) genespecific primers [PCO3, 5'-ACA CAA CTG TGT TCA CTA GC-3' and PCO4,5'-CAA CTT CAT CCA CGT TCA CC-3'] were used.

\section{PCR Amplification and Genotyping}

Polymerase chain reaction is a technique for amplification of a specific DNA sequence. The double stranded DNA of interest is denatured to separate into two individual strands. Each strand is then allowed to hybridize with a primer (renaturation). The Primertemplate duplex is used for DNA synthesis (the enzyme-DNA polymerase). These three steps denaturation, renaturation and synthesis are repeated again and again to generate multiple forms of target DNA.

The PCR was performed in a total volume of $50 \mu$ l containing 100 ng of DNA extracted from cervical cells, $50 \mathrm{mmol} \mathrm{KCl}, 10 \mathrm{mmol}$ Tris - $\mathrm{HCL}$ pH 8.3, $200 \mu \mathrm{M}$ of each dNTP, 2 to $4 \mathrm{mmol} \mathrm{MgCl2,} 1 \mathrm{U}$ Taq polymerase and 50 picomol of each primer. The primers used in this study were GP5+/GP6+ pairs with the following sequences.

GP5 + 5' TTTGTTACTGTGGTA GATACTAC

GP6 +5' GAA AAA TAA ACT GTA AATCATATTC

The mixture was denatured at $94^{\circ} \mathrm{C}$ for $5 \mathrm{~min}$, followed by 40 cycles of amplification using a PCR processor Thermal cycler. Each cycle consisted of $94^{\circ} \mathrm{C}$ for $1.5 \mathrm{~min}, 40^{\circ} \mathrm{C}$ for $2 \mathrm{~min}$, and $72^{\circ} \mathrm{C}$ for $1.5 \mathrm{~min}$. The final elongation step, lasting $4 \mathrm{~min}$., was to ensure the complete extension of the amplified product.

All positive HPV DNA PCR samples were further analyzed for genotyping of HPV. The presence of genotype 16 and 18 were investigated. HPV genotyping PCR was carried out using specific primers for amplification of the given sequence consisting of E6 region of HPV 16 and 18. The utilized sequences are: HPV 16 forward, 5'TCA AA GCC ACT GTG TCC TG-3', reverse 16,5'-CGT GTT CTT GAT GAT CTG CA-3', HPV 18, forward, 5'-GAC ACA TTG GAA AAA CTA AC-3', reverse 18, 5'-TAG TGC CCA GCCT ATG TTG TG-3. The amplified products correspond to $139 \mathrm{bp}$ for HPV 16 and 119bp for HPV 18.

\section{Discussion}

Human Papiloma virus testing has the potential to change conventional methods of cytological screening. 5 million women take part in cervical screening each year in the United Kingdom alone. HPV triage testing for women with mild cervical abnormalities has received much attention $\&$ is fast becoming part of routine care in the United States [17-25]. Human Papilloma virus test has been established as a necessary cause of cervical cancer \& its precursors including cervical intraepithelial neoplasia grade (2 \& $3 \mathrm{CIN})$. Therefore detection of high risk is becoming increasingly attractive as a primary screening tool $[26,27]$. HPV prevalence \& type distribution in our study was similar to that reported world wide. HPV prevalence from our study reflect the HPV profile of central Indian population. During the screening of the patient for infertility, their background information has been taken with respect to age, marital status, menstrual history, socioeconomic background \& cytology result. The HPV detection rate is higher in infertile patient having irregular menstrual history and those having complaint of white discharge. In our study, risk of infection with HPV is directly proportional to age 32-42years. The endocervix is lined with columnar glandular epithelium \& the ectocervix is lined with squamous epithelium. The cervix undergoes significant changes over a lifetime puberty, pregnancy \& menopause all serve to alter its structure and location. The region of the cervix where the columnar epithelium is being replaced by the new metaplastic squamous epithelium is reffered to as the transformation zone. It is at the transformation zone that most of the cellular abnormalities associated with cervical cancer arise [28]. The majority of cases represent squamous cell carcinoma \& are strongly associated with infection by high risk types of HPV, such as $16,18 \& 31$.

It is believed that high prevalence may arise from the high rate of women with abnormal cervical cytology $[29,30]$. The paper presents the first qualitative data on the psychological \& social impact of testing for high risk HPV among infertile women in HPV testing as a part of clinical trial, or specialist gynecological management for their abnormal cervical smear. The high risk HPV test is more sensitive but is specific than the cytological examination for detecting high grade dysplasia and cervical cancers. A negative finding for high risk HPV indicates that the presence of serious precancerous stage or a carcinoma is extremely unlikely. A study has shown that a combination of cytology and HPV testing at 2-yearly intervals can prove cost effective for the American healthcare system [31]. Adequate counseling of the woman by informed doctors and the existence of colposcopy facilities to clarify inconclusive findings are essential if HPV diagnosis is to prove cost effective in primary screening pro- 
grammes. After cervical screening infertile women having abnormal cervical smear. It helps the women, who wanted information about, prevalence of HPV \& their impact on their infertility.

The molecular study investigated the infection of high risk types of HPV in cervical epithelia among infertile patients [32]. It is concluded that HPV infection rate of the infertility group was higher than that of control group. Adopting PCR to genotype and quantify high risk HPV (HPV 16,18,45,33,31) DNA in cervical epithelia of the 130 infertile patients \&the 150 controls, as there is statistical significant difference in viral load between the infertility group \&the control group. And the prevalence of high Risk HPV genotype among primary infertile patients was studied.

And we found that high risk HPV genotype 16 is more prevalent among primary infertile patients of central Indian population as compared to other HPV genotype under study.

A human papilloma virus (HPV) DNA test can identify the high-risk types of HPV that are known to cause cervical cancer. The presence of these types is a strong predictor of high-grade aggressive abnormalities or cancer itself. Testing for HPV does not replace the Pap smear, but when used in combination with the Pap test this screening combination may help to more accurately detect cervical cell abnormalities than either test alone.

\section{Conclusion}

HPV PCR test is more sensitive than current screening method and able to identify specific high risk HPV genotype.

By combination of PAP test and HPV DNA test, it may be possible to minimize the risk of infection of high risk HPV type to infertile women. In the selected patients we found HPV 16 is more prominent in primary.

Molecular diagnostic techniques for detecting HPV in cervical cells. Ultimately may provide a feasible alternative to large scale cytological screening programmes.

Present study have potential to reduce false negative results and helps to manage IVF Failure Rate.

\section{References}

[1] Howley P.M. (1995) Field's Virology, Raven Press, New York.

[2] de Villiers E.M., Fauquet C., Broker T.R., Bernard H.U., zur Hausen H. (2004) Virology, 324, 17-27.

[3] Chan S.Y., Delius H., Halpern A.L., Bernard H.U. (1995) J. Virol., 69, 3074-3083.

[4] de Villiers E.M. (1997) Clin. Dermatol., 15, 199-206.

[5] Syrjanen K., Syrjanen S. (2000) Papillomavirus Infections in Human Pathology, 1st ed., John Wiley, New York, 11-52.

[6] von Knebel Doeberitz M., Bauknecht T., Bartsch D., zur Hausen H. (1991) Proc. Natl. Acad. Sci., USA., 88, 1411-1415.

[7] Haverskos H., Rohrer M., Pickworth W. (2000) Biomed Pharmacother, 54(1), 54-9.

[8] Deluca G.D., Lucero R.H., Martin de Civetta M.T., Vicente L., de Gorodner O.L., Schelover E., Alonso J.M. (2004) Rev. Ins. Med. Trop S. Paulo, 46(1), 9-12.

[9] Trofatter K.F. (1997) Am. J. Med., 102, 21-7.

[10]Moghissi K.S. (1972) Fertil Steril, 23(4), 295-306.

[11]Grimes D.A. (1999) Clinical Obstetrics Gynecology, 42(4), 972978.
[12]Knnedy S., Robinson J. and Hallam N. (1993) Br. J. Obstet. Gynaecol., 100(10), 965.

[13]Baldauf J.J., Dreyfus M., Ritter J., Meyer P. and Philippe E. (1996) Obstetrics and Gynecology, 88(6), 933-8.

[14]Fox R., Cahill D.J. (1991) British Medical Journal, 302(6769), 179.

[15]Schiffman M.H., Bauer H.M., Hoover R.N., Glass A.G., Cadell D.M., Rush B.B., Scott D.R., Sherman M.E., Kurman R.J., Wacholder S., et al. (1993) J. Natl. Cancer Inst., 85(12), 958-64.

[16]Salani R., Backes F.J., Fung Kee Fung M., Holschneider C.H., Parker L.P., Bristow R.E., Goff B.A. (2011) Am. J. Obstet. Gynecol., 204, 466-78.

[17]Solomon D., Schiffman M., Tarone R. (2001) J. Natl. Cancer Inst., 93(4), 293-299.

[18]Kjaer S.K., van den Brule A.J.C., Paull G., Svare E.I., Sherman M.E., Thomsen B.L., Suntum M., Bock J.E., Poll P.A., Meijer C.J. (2002) British Medical Journal, 325(7364), 572.

[19]Sasieni P., Cuzick J. (2002) J. Med. Screen., 9(2), 949-951.

[20]Mandelblatt J.S., Lawrence W.F., Womack S.M., Jacobson D., Yi B., Hwang Y.T., Gold K., Barter J., Shah K. (2002) Journal of the American Medical Association, 287(18), 2372-2381.

[21]Wright T.C., Schiffman M., Solomon D., Cox J.T., Garcia F., Goldie S., Hatch K., Noller K.L., Roach N., Runowicz C., Saslow D. (2004) Obstet. Gynecol., 103(2), 304-309.

[22]Wright T.D., Cox J.T., Massad L.S., Twiggs L.B., Wilkinson E.J. (2002) Journal of the American Medical Association, 287(16), 2120-2129.

[23]Wise J. (2000) British Medical Journal, 320(7235), 600.

[24]Little J. (2001) British Medical Journal, 323(7304), 109.

[25]Schiffman M., Adrianza M.E. (2000) Acta. Cytol., 44(5), 726742.

[26]Clifford G.M., Gallus S., Herrero R., Munoz N., Snijders P.J., Vaccarella S., Anh P.T., Ferreccio C., Hieu N.T., Matos E., Molano M., Rajkumar R., Ronco G., de Sanjose S., Shin H.R., Sukvirach S., Thomas J.O., Tunsakul S., Meijer C.J., Franceschi S. (2005) The Lancet, 366(9490), 991-998.

[27]Safi Z., Demirezen S., Beksac M.S., Kuzey G.M.N., Kocagoz T., Ustacelebi S., Hascelik G. (2002) Medical Network Klinik Bilimler \& Doktor, 8(1), 112-114.

[28]Schorge J.O., Knowles L.M. and Lea J.S. (2004) Current Treatment Options in Oncology, 5, 119-127.

[29]Turkish Cervical Cancer and Cervical Cytology Research Group (2009) Int. J. Gynoecol. Obstet., 106(3), 206-209.

[30]Dursun P., Altuntas B., Kuscu E., Ayhan A. (2009) Aust. NZJ Obstet. Gynaecol., 49(2), 202-6.

[31]lfetner T., Menton S., Menton M., Gomes H., GarbrechtBuettner S., Schopp B., Iftner A., Lorincz A., Bohmer G., Petry K.U. (2000) 18th International Papillomavirus Conference, Barcelona, Spain.

[32]Zhang L.D., Zhang H.M., Pej J., He G.R., Sun X.F., Li B. (2007) Zhonghua Shi Yan He Lin Chuang Bing Du Xue Za Zhi, 21(2), 159-161. [Article in Chinese] 